\title{
Legal regulation of drug advertising and its restrictions in the conditions of the Slovak Republic
}

\author{
T. Peráček ${ }^{1, \bigotimes}$, B. Mucha ${ }^{2}$, P. Brestovanská3 ${ }^{3}$ L. Strážovská ${ }^{4}$
}

\begin{abstract}
${ }^{1}$ Department of Information Systems, Faculty of Management, Comenius University in Bratislava, Odbojárov 10, 82005 Bratislava, Slovak Republic, ${ }^{2}$ Department of Economics and Finance, Faculty of Management, Comenius University in Bratislava, Odbojárov 10, 82005 Bratislava, Slovak Republic, ${ }^{3}$ Department of Economics and Finance, Faculty of Management, Comenius University in Bratislava, Odbojárov 10, 82005 Bratislava, Slovak Republic ${ }^{4}$ Department of Marketing, Faculty of Management, Comenius University in Bratislava, Odbojárov 10 82005 Bratislava, Slovak Republic
\end{abstract}

Received 23 April, 2018, accepted 16 November, 2018

Abstract The question of drug availability is a key requirement for each country. Their deficiency can cause fatal consequences for the health of the population. For this reason, the production and distribution of medicines represents the economic potential of the state, which is also protected and regulated in the Slovak Republic. Drug distribution is also part of every market economy as it is the primary form of business-to-customer (B2C) offering. At first glance, the promotion of drugs might seem to be just marketing. But this area is under the scrutiny of the Slovak legislations. From the point of view of the systemic nature of law, advertising of medicinal products is regulated both in public law and private law. This is particularly the area of administrative law, commercial law and civil or criminal law, which must respect the often complicated penetration of European law into national law. The issue of ad management and the associated availability of medicines, in our terms, is at the centre of public interest. The main aim of the authors in this paper is to examine not only the European but especially the national legal regulation of the advertising of medicines in the context of the decision-making activity of the Slovak authorities supervising compliance with the legal restrictions on the promotion of pharmaceutical products. Another goal is to identify the problems in application practice and to propose ways to eliminate identified shortcomings by specific procedures. The authors, through scientific and doctrinal interpretation, examine selected statutes of the Law on Advertising and related legislation pertaining to the issue of drug advertising. Through expert literature, jurisprudence and the decision-making processes of the administrative authorities, they seek answers to practical application problems. At the end of the contribution, they critically analyse the identified shortcomings and propose appropriate measures to eliminate them.

Keywords Advertising-management-medicine-restriction

\section{INTRODUCTION}

The need to apply the principles of the market economy in the further development of Slovak economy raises the demand for information, knowledge and experience from functioning market economies. The underlying idea is to find ways, methods and procedures to achieve this goal. Therefore, there is an increasing need for marketing, used by business entities to further their business. Marketing is considered to be a particularly effective approach to finding optimal effects, and thus to achieving the goals of entrepreneurs. Targets are different, for example from the expansion of certain opinions on smoking, to the most common and most pronounced, aimed at maximizing business profits. Advertising is one of the main forms of communication and its role is to make a product or service aware to the customer, to distinguish them from other offers and in particular to convince the customer to buy the product. Successful advertising is, therefore, according to Payne (1996) one of the key factors in the success of marketing policy.

The primary legal regulation of advertising is found in the Constitutional Law of Slovak National Council no. 460/1992 Coll. The Constitution of the Slovak Republic as amended (hereinafter "the Constitution"). In particular, advertisement

*E-mail: tomas.peracek@fm.uniba.sk

(c) European Pharmaceutical Journal 
concerns Article 55 of the Constitution, which states that the economy of the Slovak Republic is based on the principles of a social and environmentally oriented market economy, while it protects and promotes competition. The last sentence of Article 55 refers to a more detailed adjustment of this issue in separate laws. The limitation of the guarantor's right to advertisements is only permissible for the prevention of unfair competition and the dissemination of false or misleading information.

Legal regulation of advertising can also be found in several European Union legislations, of which the Directive of the European Parliament and of the Council of 6 November 2001 no. 2001/83 / EC on the Community code relates to medicinal products for human use (hereinafter referred to as the Community Code). A special place also belongs to the European Parliament and Council Directive no. 2006/114 / EC of 12 December 2006 on misleading and comparative advertising (the Misleading and Comparative Advertising Directive).

From the point of view of national regulations, advertising is primarily regulated by Act no. 147/2001 Coll. on advertising and on the amendment of certain laws (hereinafter referred to as the "Advertising Act"), or in Act no. 513/1991 Coll. Commercial Code as amended (hereinafter referred to as the "Commercial Code"). The advertisement distributed in radio and television broadcasts is modified separately, in Act no. 308/2000 Coll. on Broadcasting and Retransmission as amended (hereinafter the „Broadcasting and Retransmission Act ${ }^{\prime \prime}$ ). The advertising of pharmaceutical products (although according to the authors of this article) is regulated by 362/2011 Coll. on Medicinal Products and Medical Devices and on Amendments to Certain Laws, as amended (hereinafter the "Medicines Act"). In this case, it is mainly about adjusting the sponsorship of professional events or providing forbidden rebate.

In developed countries where advertising operates in a stabilized liberal market economy environment, the form of ethical codes has stabilized to regulate advertising ethics. Although they are legally binding rules on ad management, they are respected by special associations bringing together businesspeople in the field of advertising.

\section{OBJECTIVE OF THE CONTRIBUTION AND METHODOLOGY}

The main purpose of the authors of this contribution is to examine the European and national regulations on advertising of medicines in the context of the decision-making activities of Slovak administrations supervising compliance with the legal restrictions on the promotion of pharmaceutical products. Another goal is to identify problems in application practice, especially when deciding administrative authorities, and to propose ways to eliminate identified shortcomings by specific procedures.

Due to the nature of this contribution, several scientific methods of knowledge are applied, especially the logic method that can be used in all sciences. Furthermore, it is a method of abstraction, without which the post could be unobtrusive or chaotic in view of its wide range. The method of logical analysis as well as the analytical method for analysing the legal status and regulation of drug advertising is the necessary method for successful processing of the given issue. By using a comparative method, it is possible to gain knowledge and views on the legal regulations and the interpretation of individual institutes. Based on the scientific knowledge of valid and effective law and legal science, the doctrinal interpretation has also been used in some parts of the work.

In Slovakia, the subject of advertising has come to the forefront of legal science. By studying available literature, it is possible to conclude that there is not only professional literature, but also journalistic contributions in the field of legal regulation of advertising. In particular, journalist Tyrolová (2007), Vozár (2006) and the team of authors Siminská, Šimeková, Gyarfaš (2013), which are already out of date due to the rapid development of legislation in some parts, can be mentioned. In order to achieve the stated goal, it is necessary to review and provide a brief analysis of the decisions of the State Institute for Drug Control (SIDC) and the Ministry of Health of the Slovak Republic.

\section{ADVERTISING LAW}

The original legal basis for the adaptation of the general advertising requirements as well as the supervision of advertising was contained in Act no. 220/1996 Coll. about advertising effective until April 30, 2001. During the four years the law was in force, many shortcomings have emerged. The very definition of advertising itself was problematic; shortcomings appeared in restrictive measures to advertise some products, but also to supervise compliance with the law.

A relatively serious problem with regard to advertising law no. 220/1996 Coll. about advertising in Slovakia in 2000 arose in connection with the preparation of the European Code on Advertising, which made this law absolutely unsuitable for the current needs of regulation of the advertising market. In view of the adoption of several directives governing other areas of advertising, due to the need to implement European law in the Slovak legal order, it was abandoned because an amendment to the law was being considered. The result was the adoption of an effective law on advertising, where the legislation was based on four basic principles, such as legality, honesty, truthfulness and decency. Based on these basic ideas, general advertising requirements for products such as medicines and infant formula are formulated with specific terms and limitations set in advertising. It can be said that the legislator's intention was not to fully regulate the whole area of advertising by this law; they may also have retained the parts of the Law on Medicines, the Broadcasting and Retransmission Act or the Commercial Code governing 
certain legal institutes and the dissemination of advertising in certain media.

As regards its formulation, the Advertising Act is divided into three articles, with the focus of the legal regulation contained in the first article. The opening clause of Section 1 of the Act contains its purpose in four areas: the general regulation of advertising requirements, the conditions for the advertising of certain products, the adjustment of legal protection against the effects of misleading advertising and comparative advertising in a form that is inadmissible, as well as the scope of the supervisory authorities compliance with the provisions of the law.

The Statute of Paragraph 2 of the Act defines the basic concepts that are most important from a regulatory point of view. This is advertising that the legislature defines as a presentation or other communication in any form relating to commercial, business or other gainful activity in order to put products on the market. For comparison, some authors (Kotler, 1992) in the field of marketing explain this term differently. By advertising, I understand every paid form of non-personal presentation and support of ideas, products or services paid by an identifiable sponsor.

The basic advertising criteria are based on competition law as well as the principles of ethics and consumer protection. In the first place, according to Olšovská et al., (2015), advertising must not be deceptive. This fact is considered in terms of its content, data, characters and information. These features are assessed in particular with respect to the people to whom they are assigned or who are affected. It is also unacceptable that, as a result of misleading content, addressees are misled to influence their economic behaviour on the market or even damage them.

The definition of misleading advertising is contained in Paragraph 45 of the Commercial Code, which modifies the misleading advertising in detail. In the view of the Supreme Court of the Slovak Republic (2000) no. 5Obo 138/2000, misleading advertising is one of the signs of unfair competition. In his opinion, it must be an advertisement capable of provoking an idea that is inconsistent with reality, with the possibility that it might come to deception. In addition, the competitor's conduct must be the ability to gain a competitive advantage at the expense of another competitor.

However, the definition of ad distribution, which the law describes as a natural person or a legal entity that propagates without further explanation, is problematic. According to some authors (Siminská et al., 2013), the dissemination of advertising of medicines (as opposed to the dissemination of other advertising) does not have to be the person who acts in his business activity. In their opinion, they rely on the decision of the Court of Justice of the European Union (2009) in Daamgard. The question was whether the concept of advertising of medicinal products also involved the dissemination of information by a person who is legally and effectively independent of the manufacturer of the medicinal product. The Court of Justice of the European Union stated, inter alia, that, in principle, it is not excluded that the dissemination of information by a person independent of the manufacturer of the medicinal product falls under the definition of advertising, not necessarily business conduct. A similar issue was dealt with in 2011 by the State Institute for Drug Control (2011) in connection with the advertising of medicines on railway wagons. It then decided that the advertising of medicinal products and the person sanctioned by the unlawfulness of such advertising may not be the holder of the registration of the medicinal product. However, it is essential that advertisers have a promotional intent. In the context of the general advertising requirements contained in Statute 3 of the Advertising Act, advertising is restricted by prohibiting its appearance, which in its content violates the values protected by law. It is about protecting human life, health, the environment, freedom, conscience, socially recognized morality, property protection and so on. Particular emphasis is placed on advertising that affects minors, especially in connection with incitement to such behavior that may endanger their health, mental or moral development as well as displaying them in dangerous situations. Such limitations, in our opinion, are based on traditions and experience gained during ad development. In addition, they have a common international standard that is included in our terms and conditions in the Advertising Code of Ethics issued by the Advertising Advice Board as an association of advertising agencies in the Slovak Republic.

Additionally, the Advertising Act does not allow the advertisement to include personal data, data on the property of individuals without their prior consent. However, advertising itself to a particular addressee is not contrary to that provision, since the necessary personal data used to deliver the ad to the addressee are not part of the content of the ad as defined and are only attached to the ad.

For advertising by certain media, such as an automatic telephone answering system, telefax and e-mail, prior consent of their users is required. The purpose of such a limitation by the legislator is to prevent harassment and interference with the privacy or property rights of recipients of advertising. In the case of other means of communication, it must not be distributed directly if the addressee has refused delivery in advance. However, the method of refusing ad delivery is not defined in the law, which in practice means that the addressee can do it in any form (Dulová Spišáková et al., (2017). In real life, it's about marking the mailbox so the advertiser does not miss the ad. As a less practical and less used way of declining advertising is written notice to the postman or advertising agency. In this matter, the State Institute for Drug Control in 2014 began administrative proceedings in the matter of unlawful drug advertising in 2010. The reason for the opening of the proceeding was the form of advertising that was an imitation of a recipe. The registration certificate holder objected to the claim that the 2010 flyer, apart from the size, had nothing to do with the prescription. Different from this, for example, "Doctor Recommendation" or "Patient Reimbursement". Perhaps, in the opinion of the 
administration, it was also a hidden advertisement. However, the administrative authority could not decide on the matter because more than three years had passed since the breach of the law and the administrative procedure had to be stopped (State Institute for Drug Control, 2014).

Advertising may not be distributed if it is inconsistent with good morals and if it presents products whose production, sale, supply or use is prohibited or if it does not meet the requirements of a specific regulation.

The original law on advertising did not allow for mutual comparison of products in advertising because, as is apparent from the explanatory memorandum, the proposer of the law was based on the principle of decency. At that time, it was not appropriate for anyone in the competition to deal with the other entrepreneur's affairs and to interfere with his interests without any special reason and compulsion. Allowing comparative advertising is understood by some authors (Ovečková et al., 2017) as a breakthrough of this principle, which was necessary especially in the context of harmonization of our law with European Union law, which allowed comparative advertising in Article 4 of the Misleading and Comparative Advertising Directive. In particular, due to the sensitivity of competition, special provisions are laid down in Statutes 4 of this Act. This means that comparative advertising is only allowed in a legally defined framework and other comparative advertising is inadmissible.

\section{DRUG ADVERTISING}

Medicines are special products that have a significant impact on human health and therefore their advertising required specific provisions and adjustments in the advertising law. Strictly restrictive advertising measures affect certain groups of medicines, those that are issued only on prescription or which are covered by health insurance and medicines that are not registered in the Slovak Republic. Medicines should not be presented in advertising to encourage their excessive use or use without the need for medical examination.

In accordance with Article 86, Paragraph 1of the Medicines Directive, advertising of medicinal products under Paragraph 8, Section 1 includes „, any form of under-information, agitation or incitement to promote the prescription, delivery, sale or consumption of medicinal products" under-the-counter notification, agitation or incentives to promote prescription, delivery, sale or consumption of the drug. According to the Directive, the advertising of medicinal products also means, in particular, advertising to the general public, the advertising of medicinal products to persons qualified to prescribe them, or the issue of, visits to medical representatives responsible for the distribution of medicinal products to prescribers, the supply of samples. The national provisions essentially reproduce the wording Directive on the advertising of medicinal products (Tyrolová, 2007).

The provision of Statute 8, Paragraph 3 of the Advertising
Act exhaustively lists what cannot be considered as their advertising. This includes, for example, labeling, written information for its users, correspondence that may be supplemented with material of a non-promotional nature needed to answer a specific question about the medicine, reference material and information on, for example, changes to the packaging of the medicine, to warn of undesirable effects pharmacovigilance or business catalogue and price list on the condition that it does not contain any information on medicinal products, information relating to health or human illness, unless it contains a direct or indirect reference to the medicinal product or disclosure of information containing only the name and price of the medicinal product or the medicinal product.

Article 88 of the Medicines Directive requires Member States not to allow the advertising of selected types of medicinal products. This restriction is also passed to the Advertising Act. It is unacceptable to promote medicines not registered in the Slovak Republic. The same prohibition applies to drugs containing narcotic drugs, psychotropic substances and preparations whose expenditure is bound by medical or veterinary prescriptions. The limitation also applies to medicinal products whose expenditure is not subject to medical prescription but is reimbursed on the basis of public health insurance. An exception to this ban is vaccination campaigns organized by the marketing authorization holder or the marketing authorization holder of the marketing authorization. However, the exemption is subject to the consent of the Ministry of Health of the Slovak Republic.

With regard to the decision of the State Institute for Drug Control no. 580/2014/600, it must be pointed out that advertising of medicinal products must encourage their rational use on the basis of objective information on the characteristics of the medicinal product without exaggerating its effect. The holder of the registration certificate, in violation of this obligation in the advertisement, has encouraged the use of such a medicine, which is explicitly intended for emergency situations only. For these reasons, the Supervisory Authority, by its decision, prohibited the dissemination of advertising and imposed a fine of EUR 10,000 on the infringer (State Institute for Drug Control, 2014). The violator appealed against the decision of the first-instance body. The Ministry of Health of the Slovak Republic (2014), as the appeal body, has confirmed the ban on advertising. However, the fine of EUR 10,000 was reduced to EUR 5,000 on the ground that the offender was the first offense.

Accordind to Benda-Prokeinova et al. (2017), other restrictions relate directly to the distribution of medicinal products intended for the public for the purpose of advertising, as well as the visits of physicians during their surgery hours to promote medicinal products. The physician is forbidden to accept these people during their office hours.

The provision of Statute 8, Paragraph 9 of the Advertising Act, which excludes advertising of medicinal products intended 
for the public, may be considered to be of key importance, for example, giving the impression that medical examination or medical treatment is unnecessary, whether it offered a diagnosis or a method of treatment by correspondence. Medicines must not give the impression that their effects are guaranteed and are not accompanied by any undesirable effects or are better than or equal to the effects of another medicinal product. The rigidity of the legislation is also sharpened by sanctioning any indication in advertising that good health could be improved by taking the medicine or by indicating that a person's good health might be affected by not taking the medicine; this ban does not apply to the abovementioned vaccination campaigns, addresses exclusively or mainly children.

In the case of drugs being promoted to people authorized to prescribe and issue them, the law prohibits them from supplying, offering and promising donations, monetary and material benefits or any other benefit. According to Žulová et al. (2018), the subject of legal regulation is also the possibility of attending promotional events, which must be strictly limited to its purpose and can only be provided to healthcare workers. However, in the opinion of the legislator, the law does not preclude direct or indirect treatment for events exclusively for professional and scientific purposes. However, the condition must be fulfilled that such a treatment will always be strictly limited to the main scientific purpose of the event and will not be given to other people as a healthcare worker.

Samples of drugs, other than those containing narcotic drugs and psychotropic substances, may be provided only on written request. The authorized entity is the person authorized to prescribe medicinal products. However, it may be provided with a maximum of two samples of the smallest package of the registered medicinal product per year, labeled "FREE SAMPLE - NOT FOR SALE" and the summary of product characteristics. These samples are also subject to control and registration by the marketing authorization holder.

Paragraph 8, Section 22 of the Medicines Act also places the holder of the marketing authorization decision on other obligations. This is, for example, the creation of a scientific service responsible for information on the medicines it puts on the market. In addition, he must make available or hand over to the State Institute for Drug Control a sample of each advertisement coming from his business, together with a statement of the intended person, of the method of distribution and the date of commencement of dissemination, of ensuring compliance of the advertising of his company's medicinal products with the requirements of advertising law and others. In practice, the question arises as to whether advertising regulation also applies to homeopathic medicines. The answer is in Paragraph 24, which clearly states that the Advertising Act also applies to this category of medicinal products, with the exception of medicinal products not registered in the Slovak Republic. However, only the information and data approved at the time of its registration may be used in the advertisement of homeopathic medicinal products.

\section{PERFORMING SURVEILLANCE AND SANCTIONS FOR VIOLATING THE LAW}

The competence of state supervision of compliance with the provisions of the Act on advertising in connection with the advertising of medicinal products is entrusted to the State Institute for Drug Control and the Institute for State Control of Veterinary Bioproducts and Medicines in the Supervision of Advertising of Veterinary Medicines. The Public Health Office of the Slovak Republic and the regional public health authorities supervise the advertising of cosmetic products as well as selected foods or infant formula, nutritional supplements and other products (Vozár, 2006).

The specific procedure of the supervisory authorities consists of measures they are imposing to ensure redress. First of all, if they decide to prohibit advertising, they are entitled to require from the advertiser to submit evidence of truthfulness of factual data in case of suspicion of misleading or inadmissible comparative advertising. The called entity is legally obliged, upon request, to provide proof to the supervisor on the truthfulness of factual advertising data within 15 days of receipt of the notice. If the proof is not submitted or is inadequate, the legitimate irrefutable assumption is that the comparative advertising is inadmissible and follows the imposition of a sanction by the administration. It is particularly important to have the authority to impose on the advertiser the obligation to post the decision of the supervisory authority if it finds a violation of the law. We emphasize that the authority to ban advertising has a supervisory authority even if "only" threatens to be an inadmissible comparative advertisement (Meszároš, 2018). This is the chosen method of administrative action.

In addition to such measures, the administrative body shall impose compulsory fines, the amount of which shall be graduated. The minimum fine of up to $€ 1660$ penalizes a person entitled to prescribe or dispense drugs if they violate the prohibition to receive a gift, a monetary or material advantage or other benefit. A fine of $€ 3320$ may be imposed on the infringer if the ad does not meet the requirements for public speaking, does not observe the principles of linguistic culture, grammar and spelling rules or steady professional terminology. For an ad containing anything that denigrates human dignity offends national feeling or religious sentiment, as well as any discrimination based on sex, race and social origin, the amount of the fine is set at EUR 66,400. The maximum fine of up to EUR 166,000 may be penalized by the infringer for inadmissible comparative advertising or for the advertisement of unregistered medicines, drugs containing addictive and psychotropic substances, or medicines bound by a medical or veterinary prescription.

When imposing a fine, the supervisory authority makes use of the opportunity of proper consideration while taking 
into account the seriousness, duration, consequences of the unlawful act and whether it is a repeated violation of this law. However, the possibility of imposing a fine is subjectively time-limited for one year from the day the law enforcement authority became aware. The objective time was set for three years from the day of the violation. In practice, this means that the decision to impose a sanction must be valid within one year of the Office having learned of the breach of the sanction. This procedure is also based on the decision of the Supreme Court of the Slovak Republic (2011) no. 5Sžo $41 / 2011$, according to which, if administrative authorities fail to impose a fine within one year, proceedings under Article 30 of the Administrative Procedure Code should be stopped. However, the supervisory authority must decide no later than three years after the unlawful act has been committed. Otherwise, proceedings must be stopped and the guilty party remains uncontrolled. The fine imposed is payable within 30 days from the date on which the decision to is valid. It is revenue to the state budget. In addition to the provisions of Paragraphs 10 and 11 of the Advertising Act, the Statutes of Act no. 71/1967 Coll. on Administrative Procedure (Administrative Procedure), as amended, which is a lex specialis of administrative procedural law.

If general advertising requirements are violated, e.g. the spread of misleading advertising, and inappropriate comparative advertising or advertising requirements for certain products, sanctions are increased. Chovancová (2016) finds that the higher rate of fine in this case is justified, since misleading and inadmissible comparative advertising is a serious violation of recognized competition principles, while deceptive advertising seriously damages the consumer.

\section{RESEARCH}

As part of the comprehensive processing of the examined issue, we contacted the State Institute for Drug Control. Our aim was to analyse its decision-making activity for the period from 2013 to 2017. We found that in this period, the infringement proceedings started only 36 times. The reason was the actual finding of a potential breach of the holder of the certificate. Only in isolated cases, the administrative authority started proceedings at the initiative of a third party.

\begin{tabular}{|c|c|c|c|c|c|}
\hline Year & 2013 & 2014 & 2015 & 2016 & 2017 \\
\hline $\begin{array}{c}\text { Number of decisions } \\
\text { of SIDC in certain year }\end{array}$ & 9 & 18 & 5 & 3 & 1 \\
\hline $\begin{array}{c}\text { SIDC decided that the } \\
\text { law was not violated }\end{array}$ & 0 & 5 & 2 & 0 & 0 \\
\hline $\begin{array}{c}\text { SIDC stopped } \\
\text { proceedings }\end{array}$ & 7 & 11 & 2 & 1 & 0 \\
\hline $\begin{array}{c}\text { SIDC banned ad and } \\
\text { imposed fine }\end{array}$ & 2 & 2 & 1 & 2 & 1 \\
\hline
\end{tabular}

The analysis of the decision shows that the decision-making process was the year 2014, when the state instituted only 18 cases of possible violation of the law. On the other hand, however, in 11 cases, the proceedings stopped because of the fact that the act was time-barred. In only two cases, state decided to prohibit advertising and imposed a fine. In the following years, the number of proceedings started to sharply decline, and in 2017 it was only deciding on a single violation of the law on advertising. As a result of the administrative procedure, the ban on advertising was imposed and a fine was imposed.

\section{CONCLUSION}

The result of the research was the revealing of certain flaws in the legal regulation of drug advertising, which can cause difficulties in practice. In our opinion, the legislator did not choose the appropriate way to adapt this commodity advertisement when the advertising of drugs was regulated in Paragraph 8 of the Advertising Act, but the promotion of other pharmaceutical production is included in the Medicines Act. We also see the problem that the Medicines Act in some cases interferes with the regulation of drug advertising without respecting its terminology. As an example, we mention the modification of sponsorship of professional events in the Medicines Act. This ignores the fact that support for scientific congresses falls under the definition of drug advertising and is regulated in the Advertising Act. We also have a negative perception of including drug samples under the definition of discounts in the Medicines Act, while drug samples are tax-deductible in the advertising law.

However, we have found that the legislator also caused another problem by entrusting the supervision of advertising to two different bodies. The first-degree supervisory authority under the Advertising Act is the State Institute for Drug Control and under the Medicines Act it is the Ministry of Health of the Slovak Republic. Probably only theoretically, a situation could arise that the holder of the certificate, by supporting a particular event, fulfills the factual nature of an administrative offense under the Medicines Law and also under the Advertising Act. In our view, they could be penalized for violating both laws and two different bodies. In practice, however, this approach would come across the principle of "ne bis in idem " ("not twice in the same case"). This example points to the inconsistency and practical difficulties associated with the division of one type of regulation into two rules controlled by two different bodies. The chaos of legislation only confirms and multiplies the position of the Ministry of Health of the Slovak Republic. This central state administration body performs not only the function of the first-instance supervisory body but also the function of the appeal body against the decisions of the State Institute for Drug Control. 
As can be seen from our findings, the fundamental problem of regulating and controlling drug advertising is seen in the provisions of Statutes 11, Paragraph 5 of the Advertising Act. This provision establishes an objective and subjective time period until the administrative authority has to make a decision on the violation of the law. From the analysis of the State Institute for Drug Control for the years 2013 to 2017, we found that, despite the proven violations of the Advertising Act, the administrative body had to seal the proceedings largely because of the expiration of time, and the culprit passed the sentence. A suitable solution to this problem can be found in an amendment to the provision of the law, which would be an objective time for the decision on the matter to be extended to five years and a subjective period to three years.

\section{References}

[1] Act no. 147/2001 Coll. on advertising and on the amendment and supplementation of certain laws, as amended,

[2] Act no. 308/2000 Coll. on broadcasting and retransmission, as amended

[3] Act no. 362/2011 Coll. on Medicinal Products and Medical Devices and on Amendments to Certain Acts, as amended

[4] Act no. 513/1991 Coll. Commercial Code, as amended

[5] Act no. 71/1967 Coll. on Administrative Procedure (Administrative Procedure), as amended

[6] Benda-Prokeinová R., Dobeš K., Mura L., Buleca J. Engel's Approach as a tool for estimating consumer behaviour. E \& M Ekonomie a Management. 2017;20:15-29.

[7] Constitutional Act of Slovak national council no. 460/1992 Coll. Constitution of the Slovak Republic, as amended

[8] Decision of the Ministry of Health SR no. S07207-OP-2014 of 02.092014

[9] Decision of the State Institute for Drug Control no. 11/534 of 31. 01.2011

[10] Decision of the State Institute for Drug Control no. 580/2014/600 of 22. 05.2014

[11] Directive of the European Parliament and of the Council of 6 November 2001, 2001/83 / EC on the Community code relating to medicinal products for human use.

[12] Dulová Spišáková E., Mura, L., Gontkovičová, B., Hajduová, Z. 2017. R\&D in the context of Europe 2020 in selected countries. Economic Computation and Economic Cybernetics Studies and Research. 2017;51:243 - 261.

[13] European Parliament and Council Directive No. 2006/114 / EC of 12 December 2006 on misleading and comparative advertising

[14] Chovancová J. Philosophy of democracy and principles of democracy. Progress in economic sciences. 2016;3:41-51.

[15] Judgment of the Court of Justice of 2 April 2009 in Case C-421/07 Anklagemyndigheden /Frede Damgaard [2009] ECR p. I-026929, section 21

[16] Judgment of the Supreme Court of the Slovak Republic no. 5 Obo $138 / 2000$

[17] Judgment of the Supreme Court of the Slovak Republic no. 5Sžo 41/2011

[18] Kotler P. Marketing management. Praha: Victoria publishing; 1992.

[19] Mészáros M. "Employing" of self-employed persons. Central European Journal of Labour Law and Personnel Management. 2018;1:31-50.
[20] Olšovská A., Mura L., Švec M. 2015. The most recent legislative changes and their impact on interest by enterprises in agency employment: What is next in human resource management? Problems and Perspectives in Management. 2015;13:47-54.

[21] Ovečková O., Csach K., Frindrich J. et al. Obchodný zákonník Vel'ký komentár Zväzok 1 (§1 až 260). Bratislava: Wolters Kluwer; 2017.

[22] Payne A. Marketing Služeb. Praha: Grada publishing; 1996.

[23] Siminská E., Šimeková, Z., Gyárfáš, J. Reklama liekov v kontexte európskej a slovenskej legislatívy. Bulletin slovenskej advokácie. 2013;10:14-26.

[24] Tyrolová M. Aktuálne aspekty právnej úpravy reklamy liekov. Justičná revue. 2007;11:1422-1425.

[25] Vozár J. Reklama na lieky. Duševné vlastníctvo. 2006;10:33-38.

[26] Žul'ová J., Švec M., Madleňák, A. Personality aspects of the employee and their exploration from the GDPR perspective. Central European Journal of Labour Law and Personnel Management. 2018;1:51-60. 